\title{
The Relationships among Community Type, Peat Layer Thickness, Belowground Carbon Storage and Habitat Age of Mangrove Forests in Pohnpei Island, Micronesia
}

\author{
Kiyoshi Fujimoto ${ }^{*}$, Yukira Mochida ${ }^{2}$, Takao Kikuchi², Ryuichi Tabuchi ${ }^{3}$, \\ Yasumasa Hirata ${ }^{3}$, Saimon Lihpai ${ }^{4}$ \\ ${ }^{1}$ Faculty of Policy Studies, Nanzan University, Seto, Japan \\ ${ }^{2}$ Graduate School of Environmental and Information Sciences, Yokohama National University, Yokohama, Japan \\ ${ }^{3}$ Forestry and Forest Products Research Institute, Tsukuba, Japan \\ ${ }^{4}$ Division of Forestry and Marine Enforcement, Department of Land \& Natural Resources, Pohnpei State \\ Government, Kolonia, The Federated States of Micronesia \\ Email: ${ }^{*}$ kfuji@nanzan-u.ac.jp
}

Received 25 December 2014; accepted 9 January 2015; published 16 January 2015

Copyright (C) 2015 by authors and Scientific Research Publishing Inc.

This work is licensed under the Creative Commons Attribution International License (CC BY).

http://creativecommons.org/licenses/by/4.0/

(c) $\underset{\mathrm{EY}}{\text { (i) }}$ Open Access

\section{Abstract}

This paper quantifies the relationships among community type, peat layer thickness and habitat age of the mangrove forests in Pohnpei Island, Micronesia and provides a discussion concerning the primary succession and the belowground carbon storage of the main mangrove community types. The ages of the habitat were estimated from a relationship between the thickness of the mangrove peat layer and the formative period, which was decided by calibrated radiocarbon ages. Mangrove communities in the coral reef type habitat were generally arranged in the following order, from seaward to landward: 1) the Rhizophora stylosa or Sonneratia alba community (I or II communities), 2) the typical subunit of the $S$. alba subcommunity of the Rhizophora apiculataBruguiera gymnorrhiza community (III(2)a subunit) and 3) the Xylocarpus granatum subunit of the same subcommunity of the same community (III(2)b subunit). Their habitat ages were estimated to be younger than 460 years, between 360 and 1070 years and between 860 and 2300 years, respectively. Based on these results and other evidences such as photosynthetic characteristics and pollen analysis derived from the previous studies, the primary succession was inferred to have progressed in the order mentioned above. Belowground stored carbon for the main community types in the coral reef type habitat were estimated to be less than $370 \mathrm{t} \mathrm{C} \mathrm{ha}^{-1}$ for the I and the II communities, between 290 and $860 \mathrm{t} \mathrm{Cha}^{-1}$ for the III(2)a subunit and between 700 and

\footnotetext{
${ }^{*}$ Corresponding author.
}

How to cite this paper: Fujimoto, K., Mochida, Y., Kikuchi, T., Tabuchi, R., Hirata, Y., \& Lihpai, S. (2015). The Relationships among Community Type, Peat Layer Thickness, Belowground Carbon Storage and Habitat Age of Mangrove Forests in Pohnpei Island, Micronesia. Open Journal of Forestry, 5, 48-56. http://dx.doi.org/10.4236/ojf.2015.51006 


\title{
$1850 \mathrm{t} \mathrm{Cha}^{-1}$ for the III(2)b subunit.
}

\section{Keywords}

\author{
Mangrove Forest, Community Type, Habitat Age, Belowground Carbon Storage, Primary \\ Succession
}

\section{Introduction}

The mangrove forests on Pohnpei Island, in the Federated States of Micronesia, have not significantly suffered from human impact. This means that a clear zonation of mangrove communities can be found on the Island.

An overview of the mangrove forests in Pohnpei that describes their spatial distribution, total area and timber volume was provided by the USDA Forest Service (e.g. MacLean et al., 1986; Petteys et al., 1986). On the other hand, we have studied formative processes of mangrove habitats to predict the effects of anticipated rapid sea-level rise induced by global warming (e.g. Miyagi \& Fujimoto, 1989; Kikuchi, 1995) and also elucidated forest structure, dynamics, biomass, productivity, and carbon storage abilities of mangrove forests across different habitat types on five permanent plots of 0.1 to 1 ha (e.g. Fujimoto et al., 1995b, 1999b, 2013; Tabuchi, 2006).

Through these studies, we have accumulated the phytosociological data necessary to classify community types, as well as the geomorphological data necessary to estimate the peat depth and habitat age. We also discussed the successional trends using the data obtained before 1993 to describe the relationship between community types and peat depth in relation to rise in sea-level (Kikuchi et al., 1999).

This paper clarifies the relationships among community type, thickness of the mangrove peat layer and habitat age using our recent data along with the data used in Kikuchi et al. (1999). In this paper "Habitat age" is defined as the number of years that have elapsed since pioneer mangrove species colonized a site. Although the relationship between mangrove vegetation and site environments such as geomorphological conditions and physiological adaptations to physico-chemical gradients has been discussed extensively (e.g. Thom, 1967; Ball, 1988), the ages of habitats with different community types is unknown.

The results of this study will contribute to the discussion on the successional series of mangrove forests in the Pacific region and estimate the spatial distribution of stored belowground carbon as well as aboveground. The relationship between belowground carbon storage and community type was not clarified in our previous study (Fujimoto et al., 1999b), though the general value of the coral reef type habitat was discussed. In this paper we also discuss primary succession and the stored belowground carbon per unit area for each main community type.

\section{Study Area and Methods}

Pohnpei is a high oceanic island of about 35,500 ha that consists of Tertiary volcanic rocks and is surrounded by barrier reefs. Annual rainfall is approximately 5000 to $6000 \mathrm{~mm}$, with no apparent dry season. The annual mean temperature is $26.4^{\circ} \mathrm{C}$ and the annual variation is not more than $1^{\circ} \mathrm{C}$ from the mean temperature. Mean tidal range at Pohnpei Harbor is about $70 \mathrm{~cm}$, and the maximum spring tidal range is approximately $150 \mathrm{~cm}$.

Mangrove habitats develop mainly on the reef flats fringing the island, although some of them are situated in estuaries (Figure 1). This creates two main habitat types, with the former habitat referred to as the coral reef type and the latter as the estuary type. The substrata of these mangrove habitats mainly consist of peat (Miyagi \& Fujimoto, 1989; Fujimoto et al., 1995a, 1995b). Based on phytosociological method, the mangrove forests in Pohnpei have been classified into three community types, along with six subcommunities and five subunits, by Mochida et al. (2006) as follows.

I. Rhizophora stylosa community

(1) Typical subcommunity

(2) Enhalus acoroides subcommunity

(3) Bruguiera gymnorrhiza subcommunity

II. Sonneratia alba community 


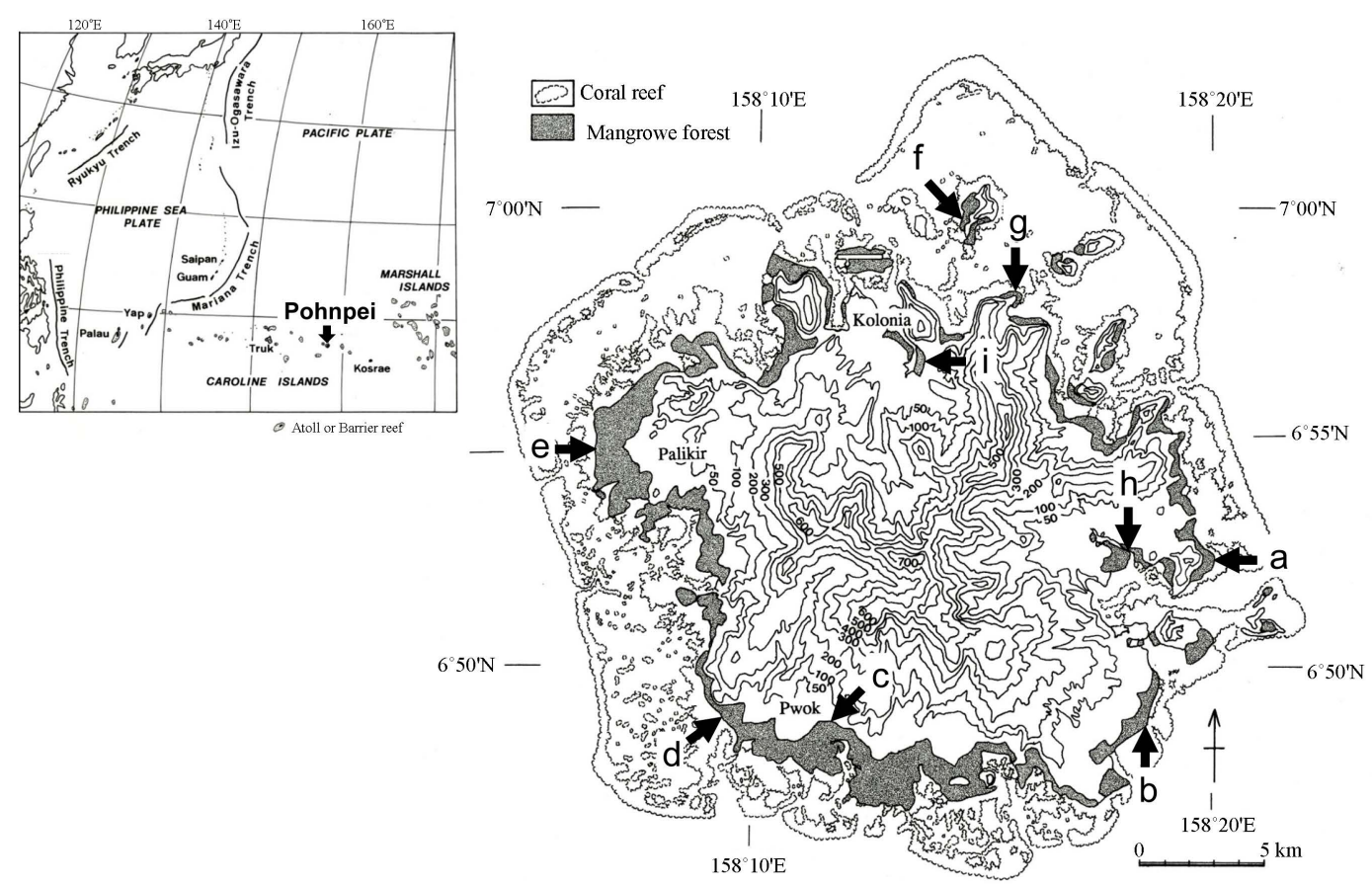

Figure 1. Map showing the study areas and location of transects.

\section{Rhizophora apiculate—Bruguiera gymnorrhiza community}

(1) Typical subcommunity

(2) Sonneratia alba subcommunity

a) Typical subunit;

b) Xylocarpus granatum subunit;

c) Lumnitzera littorea subunit.

(3) Xylocarpus granatum-Heritiera littoraris subcommunity

a) Typical subunit;

b) Barringtonia racemosa subunit.

In this paper we use a simple coding system to describe the community types, for example; I(1) describes the typical subcommunity of the $R$. stylosa community and III(2)a indicates the typical subunit of the S. alba subcommunity of the Rhizophora apiculata-Bruguiera gymnorrhiza community.

The relationship among vegetation, sediment and topography was examined for nine transects. Seven transects were situated in the coral reef type habitat and two were in the estuary type habitat (Figure 1). Four transects were along a line of permanent plots established in 1994, 2002 and 2003 (Fujimoto et al., 1995b; Tabuchi, 2006). Transects a to e, h and I, which were examined between 1988 and 1993, have been described in our previous publications (Fujimoto et al., 1995a, 1995b; Miyagi \& Fujimoto, 1989; Miyagi et al., 1995). The topography along the transects was surveyed using a pocket compass with a level. A hiller-type peat sampler was used to examine sediments and to collect the samples for radiocarbon dating. The results were compiled in Figure 2 and Figure 3.

Radiocarbon ages obtained from mangrove peat in our previous studies, as well as from lower tidal-flat deposits that were overlain by mangrove peat, were calibrated to calendar year using CALIB 7.0 (Table 1). A standard $\delta^{13} \mathrm{C}$ value of mangrove plant bodies of $-27 \% \pm \pm 3 \%$ (e.g. Fujimoto et al., 1999a, 1999b) was applied to calibrate for the samples that had not obtained a $\delta^{13} \mathrm{C}$ value. The calibrated ages were obtained from a 50-year moving-average calibration curve.

The habitat age was then estimated from a resemble equation showing the relationship between the thickness of the mangrove peat and the formative period decided by the calibrated ages.

The stored belowground carbon for each main mangrove community was estimated using the data obtained from Fujimoto et al. (1999b), as well as the relationship between community type and the peat depth. 
(a)

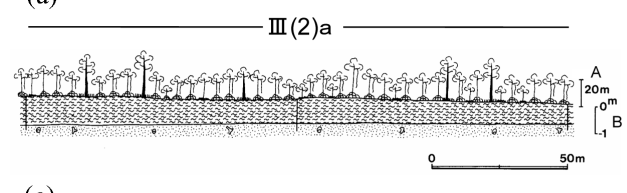

(c)

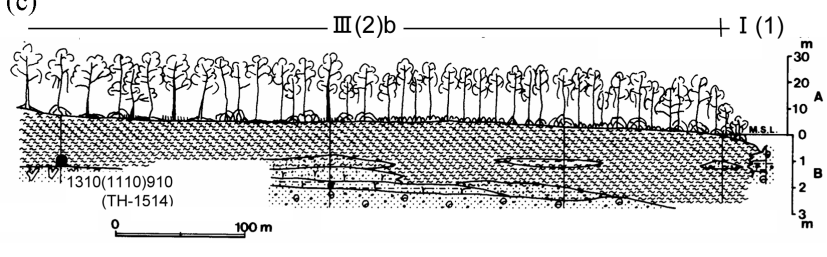

(b)

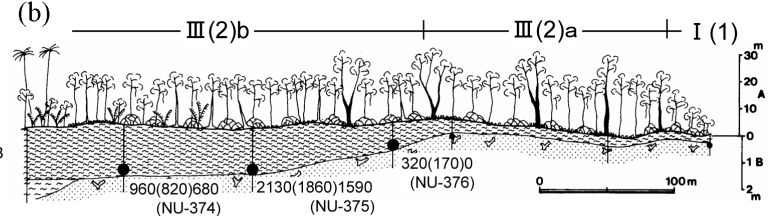

(d)

(e)
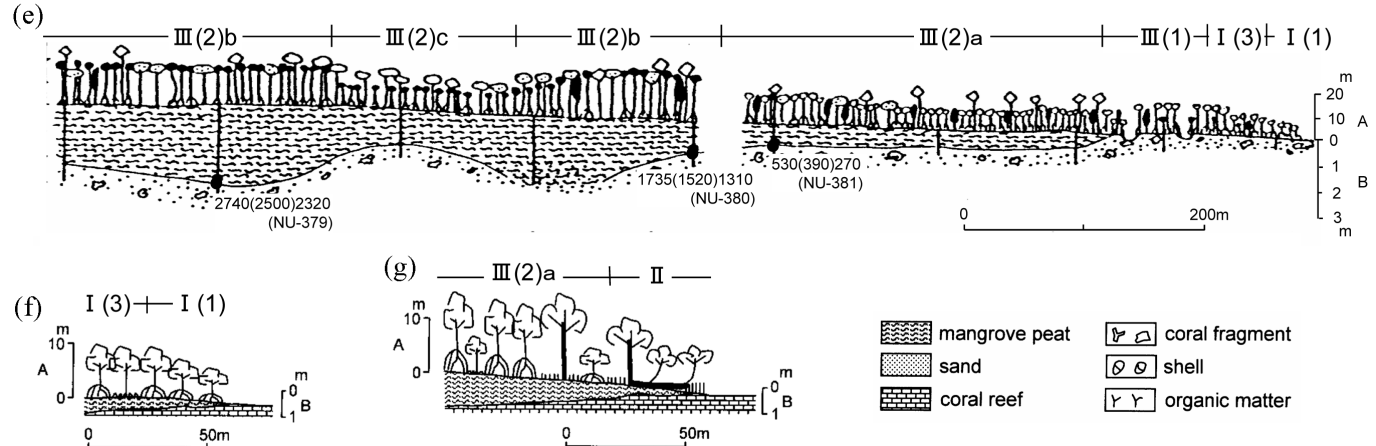

(g)

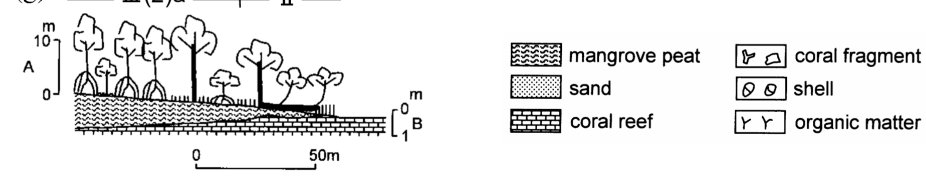

Figure 2. Community type, landform and sediments along transects in the coral reef type habitat. (a) Revised Fujimoto et al. (1995b); (b) Revised Fujimoto et al. (1995a); (c) (d) Revised Miyagi \& Fujimoto (1989); (e) Revised Miyagi et al. (1995); (f) (g) This study. A: Scale for representing tree height, B: Vertical scale for to represent the topographic and geologic profile.

(h)

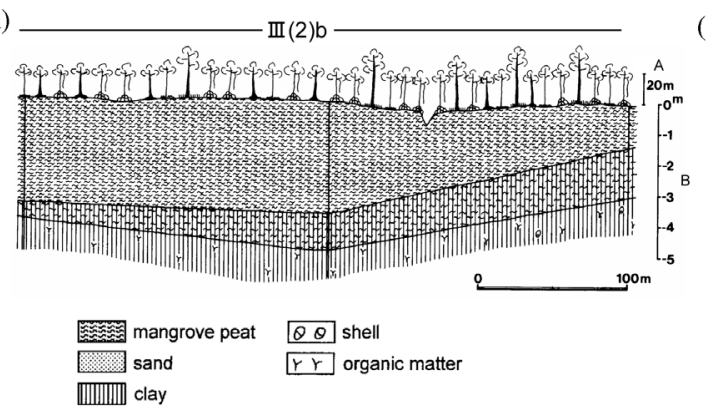

(i) $-\mathrm{NF}+\mathrm{II}(2) \mathrm{b}-\mathrm{FWSF}$

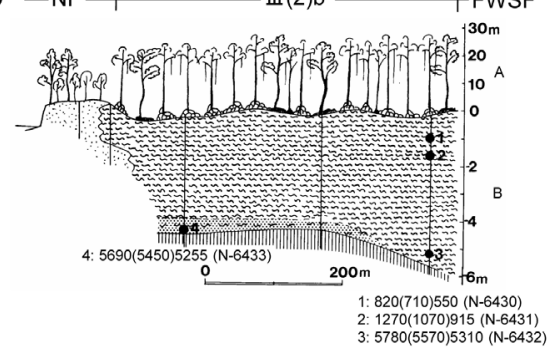

Figure 3. Community type, landform and sediments along transects in the estuary type habitat. (h) Revised Fujimoto et al. (1995b); (i) Revised Fujimoto et al. (1995a). A: Scale for representing tree height, B: vertical scale to represent the topographic and geologic profile, NF: Natural levee forest, FWSF: Freshwater swamp forest.

\section{Results}

\subsection{Characteristics of Community Types along Transects}

Of the community types described by Mochida et al. (2006), seven were found along the transects. These community types were:I(1) subcommunity, I(3) subcommunity, II community, III(1) subcommunity, III(2)a subunit, III(2)b subunit and III(2)c subunit (Figure 2 \& Figure 3).

The I(1) subcommunity developed along the seaward edge of the coral reef type habitat. It was 15 to $50 \mathrm{~m}$ in depth (Figures 2(b)-(f)) and was characterized by a tree height of less than $10 \mathrm{~m}$ and a high density of prop roots. The II community rarely appeared along the seaward edge of the coral reef type habitat, which was 10 to $20 \mathrm{~m}$ in depth (Figure 2(g)) and was characterized by prostrate trees and a high density of pneumatophores. The III(1) subcommunity appeared behind the I(3) subcommunity (Figure 2(e)). The III(2)a subunit usually 
Table 1. Radiocarbon ages obtained from the mangrove peat and the lower tidal-flat deposit on Pohnpei, Micronesia.

\begin{tabular}{|c|c|c|c|c|c|c|c|c|}
\hline Lob. Code & $\begin{array}{l}\text { Depth } \\
\text { (cm) }\end{array}$ & $\begin{array}{l}\text { Measuredage } \\
\left({ }^{14} \mathrm{C} \mathrm{BP}, \pm 1 \sigma\right)\end{array}$ & $\begin{array}{c}\text { Conventional } \\
\text { age } \\
\left({ }^{14} \mathrm{C} \mathrm{BP}, \pm 1 \sigma\right)\end{array}$ & $\begin{array}{c}2 \sigma \text { calibrated } \\
\text { age } \\
\text { (cal BP) }\end{array}$ & $\begin{array}{l}\text { Sampled } \\
\text { year } \\
\text { (AD) }\end{array}$ & $\begin{array}{l}\text { Formative } \\
\text { period } \\
\text { (years) }\end{array}$ & $\begin{array}{l}\text { Mean } \\
\text { depth } \\
\text { (cm) }\end{array}$ & $\begin{array}{l}\text { Accumulation } \\
\text { rate } \\
\text { (mm/yr) }\end{array}$ \\
\hline IAAA-1021391) & $80-85$ & $350 \pm 20$ & $320 \pm 30$ & $460-(390)-310$ & 2010 & 450 & 82.5 & 1.8 \\
\hline NU-374 $4^{2)}$ & $180-190$ & $930 \pm 80$ & $900 \pm 90$ & $960-(820)-680$ & 1990 & 860 & 185 & 2.2 \\
\hline NU-375 & $170-180$ & $1950 \pm 100$ & $1920 \pm 110$ & 2130-(1860)-1590 & 1990 & 1900 & 175 & 0.9 \\
\hline NU-376 ${ }^{2)}$ & $93-107$ & $190 \pm 70$ & $160 \pm 85$ & 420-390, 320-(170)-0 & 1990 & 210 & 100 & 4.8 \\
\hline NU-379) & $270-285$ & $2450 \pm 80$ & $2420 \pm 90$ & 2740-(2500)-2320 & 1991 & 2541 & 277.5 & 1.1 \\
\hline NU-380 3 ) & $130-140$ & $1650 \pm 90$ & $1620 \pm 100$ & 1735-(1520)-1310 & 1991 & 1561 & 135 & 0.9 \\
\hline NU-381 $1^{3)}$ & $80-90$ & $370 \pm 70$ & $340 \pm 85$ & $530-(390)-270,200-150,10-0$ & 1991 & 431 & 85 & 2.0 \\
\hline NU-382 $2^{4)}$ & $90-100$ & $270 \pm 70$ & $240 \pm 85$ & $480-(270)-70,40-0$ & 1991 & 311 & 95 & 3.1 \\
\hline NU-383 ${ }^{4)}$ & $155-170$ & $1590 \pm 120$ & $1560 \pm 130$ & $1790-1770,1765-(1470)-1260$ & 1991 & 1511 & 162.5 & 1.1 \\
\hline NU-901 $1^{5)}$ & $110-125$ & $1380 \pm 95$ & $1350 \pm 110$ & $\begin{array}{c}1500-1450, \\
1440-(1260)-1030,1020-1000\end{array}$ & 1997 & 1307 & 117.5 & 0.9 \\
\hline $\mathrm{NU}-902^{5)}$ & $193-208$ & $1800 \pm 95$ & $1770 \pm 110$ & 1920-(1690)-1420 & 1997 & 1737 & 200.5 & 1.2 \\
\hline TH-1514 & $175-200$ & $1210 \pm 100$ & $1180 \pm 110$ & 1310-(1110)-910 & 1988 & 1148 & 187.5 & 1.6 \\
\hline $\mathrm{TH}-1515^{6)}$ & $204-219$ & $1860 \pm 110$ & $1830 \pm 120$ & 2040-(1760)-1500, 1465-1430 & 1988 & 1798 & 211.5 & 1.2 \\
\hline TH-1517 & $125-150$ & $1310 \pm 100$ & $1280 \pm 110$ & 1370-(1190)-960 & 1988 & 1228 & 137.5 & 1.1 \\
\hline N-6428 & $90-120$ & $740 \pm 80$ & $710 \pm 90$ & $810-(660)-525$ & 1992 & 702 & 105 & 1.5 \\
\hline N-6429 & $150-180$ & $720 \pm 80$ & $690 \pm 90$ & $780-(650)-520$ & 1992 & 692 & 165 & 2.4 \\
\hline $\mathrm{N}-6430^{2)}$ & $90-120$ & $790 \pm 80$ & $760 \pm 90$ & $\begin{array}{l}\text { 900-850, 840-830, } \\
\text { 820-(710)-550 }\end{array}$ & 1992 & 752 & 105 & 1.4 \\
\hline $\mathrm{N}-6431^{2)}$ & $150-180$ & $1170 \pm 80$ & $1140 \pm 90$ & 1270-(1070)-915 & 1992 & 1112 & 165 & 1.5 \\
\hline${ }^{*} \mathrm{~N}-6432^{2)}$ & $520-550$ & $4870 \pm 115$ & $4840 \pm 125$ & 5890-5790, 5780-(5570)-5310 & 1992 & - & - & - \\
\hline${ }^{*} \mathrm{~N}-6433^{2)}$ & $390-420$ & $4760 \pm 95$ & $4730 \pm 110$ & 5690-(5450)-5255, 5180-5060 & 1992 & - & - & - \\
\hline${ }^{* *}$ IAAA-120353 ${ }^{1)}$ & $310-320$ & $2580 \pm 30$ & $2550 \pm 30$ & $2750-(2710)-2690,2640-2510$ & 2011 & - & - & - \\
\hline${ }^{* *}$ Beta-98286 ${ }^{5)}$ & $330-360$ & $2610 \pm 60$ & $2570 \pm 60$ & 2790-(2640)-2450 & 1997 & - & - & - \\
\hline${ }^{* *}$ Beta- $98287^{5)}$ & $450-480$ & $3240 \pm 60$ & $3200 \pm 60$ & $3575-(3430)-3320,3290-3280$ & 1997 & - & - & - \\
\hline${ }^{* *}$ Beta- $98288^{5)}$ & $270-300$ & $3090 \pm 70$ & $3050 \pm 70$ & 3410-(3260)-3045 & 1997 & - & - & - \\
\hline
\end{tabular}

${ }^{1)}$ This study, ${ }^{2)}$ After Fujimoto et al. (1995a), ${ }^{3)}$ After Miyagi et al. (1995), ${ }^{4)}$ After Omoto (1997), ${ }^{5)}$ After Fujimoto et al. (1999b), ${ }^{6)}$ After Miyagi \& Fujimoto (1989), ${ }^{7}$ Fujimoto et al. (unpublished). "Samples obtained from bottom horizon of a mangrove peat layer in an estuary type mangrove habitat, *Samples obtained from lower tidal-flat deposits. Value in parenthesis in the calibrated age shows a median probability.

appeared behind the I and II communities (Figure 2(b), Figure 2(e) \& Figure 2(g)). The III(2)b subunit, which occupied the widest area of the mangrove forests in Pohnpei, generally appeared behind the III(2)a subunit in coral reef type habitats (Figures 2(b)-(e)) and in estuary type habitats (Figure 3). The III(2)c subunit generally appeared on the inland side of mangrove forests (Figure 2(e)).

\subsection{Relationships between Community Type and the Thickness of the Mangrove Peat Layer}

Figure 4 shows the distribution of peat depth under the main community types obtained from the coral reef type habitat. The peat depth of the I(1) subcommunity and the II community was usually less than $50 \mathrm{~cm}$ (Figure 2(b), Figures 2(e)-(g) \& Figure 4). The I(3) subcommunity stood on about a $55 \mathrm{~cm}$ deep of mangrove peat layer, though only three points were measured (Figure 4). While the thickness of the peat layer under the III(2)a subunit was between 45 and $133 \mathrm{~cm}$ (Figure 2(a), Figure 2(b), Figure 2(e), Figure 2(g) \& Figure 4), under the III(2)b subunit it was between 107 and $285 \mathrm{~cm}$ (Figures 2(b)-(e) \& Figure 4). The peat layer under the III(2)c subunit on Transect c was $138 \mathrm{~cm}$, which was thinner than the III(2)b subunit along the same transect (Figure 2(c) \& Figure 4). The peaty layer of the estuary type habitat, which was generally covered by the III(2)b subunit except on river banks, ranged from 300 to $500 \mathrm{~cm}$ deep (Figure 3). 


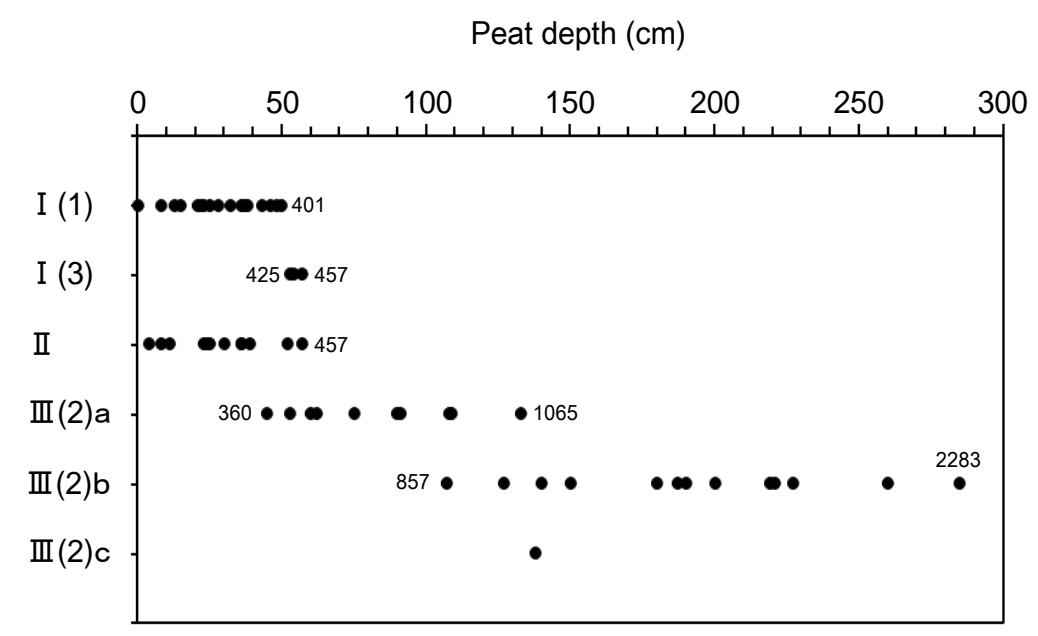

Figure 4. Range of peat depth under the main community types of the coral reef type habitat. Values in the figure show the minimum and maximum habitat ages (years) obtained from the equation in Figure 5.

\section{Discussion}

\subsection{Relationship between the Thickness of Mangrove Peat and the Formative Period}

In Kosrae Island, Micronesia, which is located about $550 \mathrm{~km}$ east of Pohnpei, mangrove forests inhabited estuaries only before $2100{ }^{14} \mathrm{C}$ BP $(2100 \mathrm{cal} \mathrm{BP})$ and retreated landward between 4100 and $3800{ }^{14} \mathrm{C}$ BP (between 4500 and $4200 \mathrm{cal} \mathrm{BP}$ ) because of a rapid sea-level rise (Fujimoto et al., 1996). The sea level reached relatively high stand around $3700{ }^{14} \mathrm{C}$ BP (4100 cal BP) before the last lower sea-level phase around $2100{ }^{14} \mathrm{C} \mathrm{BP}$. Mangrove forests expanded on coral reefs by $2100{ }^{14} \mathrm{C}$ BP with the sea-level fall. Although the sea level has gradually risen over the past 2100 years, the habitats have been maintained by an accumulating of mangrove peat.

In Pohnpei, calibrated ages older than 2500 cal BP have not been obtained from mangrove peat in coral reef type habitats (Table 1 \& Figure 2). However, ages around 5500 cal BP and between 3400 and 2600 cal BP were obtained from the bottom horizon of mangrove peat and from the lower tidal-flat deposits overlain by mangrove peat in estuary type habitats (Figure 3), respectively. This evidence suggests that the pattern of sea-level changes and mangrove habitat dynamics on Pohnpei are the same as on Kosrae, and that coral reef type mangrove forests did not exist there before 2500 cal BP, although mangrove forests did inhabit estuaries. Therefore, on Pohnpei, the relationship between the thickness of the mangrove peat and the formative period can only be analyzed for the last 2500 years.

Previous studies have demonstrated that, despite a gradual sea-level rise of 1 to $2 \mathrm{~mm} \mathrm{yr}^{-1}$, most mangrove habitats with peat substrates in the Asia-Pacific region have been maintained during the last 2000 years by accumulating peat (Fujimoto et al., 1995a, 1996, 1999a). Therefore, mangrove peat accumulation rates indicating over $2 \mathrm{~mm} \mathrm{yr}^{-1}$ are possibly contaminated by younger carbon through processes such as root penetration.

Figure 5 shows the relationship between the sampling depth of mangrove peat for radiocarbon dating and the calibrated age during the last 2500 years. The two outliers, NU-376 and NU-382, were rejected by a SmirnovGrubbs test $(p<0.05)$ using EZR downloaded from the web site of Jichi Medical University

(http://www.jichi.ac.jp/saitama-sct/SaitamaHP.files/download.html). The peat accumulation rate may have varied during the last 2500 years depending on the changes of the rate of relative sea-level rise. However, it is difficult to understand the changes using existing data. Thus, we approximated the relationship between the thickness of mangrove peat and the formative period by a linear expression to estimate habitat age.

\subsection{Relationship between Community Type, Habitat Age and Succession}

Mangrove communities in the coral reef type habitat in Pohnpei are generally arranged in the following order, from seaward to landward:1) the I or the II community, 2) the III(2)a subunit and 3) the III(2)b subunit. Using the equation in Figure 5, habitat ages of the I(1) subcommunity, the I(3) subcommunity, the II community, 


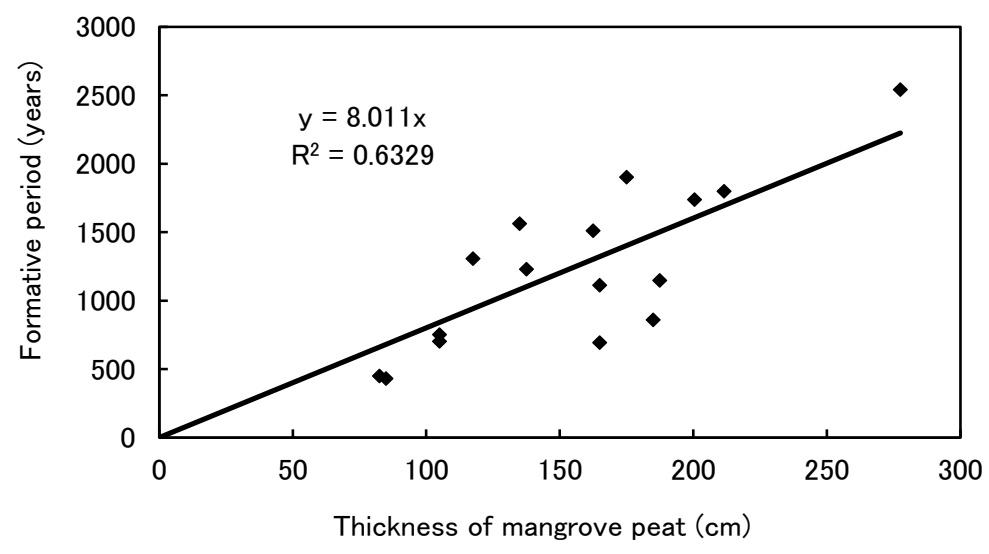

Figure 5. Relationship between the thickness of the mangrove peat layer and the formative period in Pohnpei, Micronesia.

the III(2)a subunit and the III(2)b subunit were estimated to be younger than 400 years, between 430 and 460 years, younger than 460 years, between 360 and 1070 years and between 860 and 2280 years, respectively (Figure 4).

These results suggest that the primary succession of mangrove forest in Pohnpei has progressed in the order mentioned above, along with a relative rise in the ground level as a result of peat accumulation. The results also suggest that it took about 400 years and 1000 years for the formation of the III(2)a subunit and the III(2)b subunit, respectively.

If the peat accumulation rate has equilibrated with the rate in the rise in sea level, the succession may not have proceeded even if enough time has elapsed. During the last 1000 years, the ground level has relatively risen as a result of peat accumulation; consequently allowing succession to progress, though succession is affected not only by changes in sea level but also various other factors such as seed supply and photo-environment.

Imanishi \& Kira (1944) inferred almost the same primary successional series as mentioned above based on the arrangement of community types. However, they placed the $S$. alba dominant forest, which, judging from their description, seems to include the II community and the III(2)a subunit, between the $R$. stylosa-R. apiculata forest (corresponding to the I community) and the X. granatum-S. alba-B. gymnorrhiza forest (corresponding to the III(2)b subunit). Kikuchi et al. (1999) also described nearly the same successional trends as mentioned above, though the $S$. alba community was not recognized.

Studies analyzing different variables, such as forest dynamics, photosynthetic characteristics and pollen analysis, are needed to reinforce the discussion concerning the mangrove successional series. We established permanent plots in Pohnpei mangrove forests and have monitored forest dynamics since 1994 in order to ascertain the successional characteristics of these forests (Fujimoto et al., 1995b, 2013; Tabuchi, 2006). On the other hand, Kitao et al. (2003) found that the light-saturated electron transport rate was higher in S. alba and $R$. stylosa $>R$. apiculata and B. gymnorrhiza $>X$. granatum. Additionally, the tolerant capacity for photo-inhibition was higher in $S$. alba and $R$. stylosa $>R$. apiculata $>B$. gymnorrhiza and $X$. granatum. These results support the successional series mentioned above. Moreover, Yamanaka \& Kikuchi (1995) reported that the pollen density of Sonneratia was relatively high throughout the peat layer except immediately at the surface and that the pollen density of Rhizophoraceae gradually increased toward the surface of the peat layer, with a final and rapid increase at the surface. This was found in a boring core obtained from the landward part of Transect i, although it was impossible to identify the pollen at genus or species level for Rhizophoraceae. Nevertheless, the results are consistent with this study's inference on succession.

The differences of formative initial conditions between the I and the II communities and the formative processes of the III(2)c subunit are not yet clear. Further studies are needed to fully understand these problems.

\subsection{Belowground Carbon Storage for the Main Community Types}

The clear relationship between community type and peat depth enables us to estimate the stored belowground carbon per unit area for each community type using the results of Fujimoto et al. (1999b), a value of $1300 \mathrm{t} \mathrm{C}$ $\mathrm{ha}^{-1}$ up to $2 \mathrm{~m}$ depth of mangrove peat in the coral reef type habitat in Pohnpei, and the known peat depth for 
each community type.

The peat depths are less than $57 \mathrm{~cm}$ for the Iand the II communities, 45 to $133 \mathrm{~cm}$ for the III(2)a subunit and 107 to $285 \mathrm{~cm}$ for the III(2)b subunit (Figure 4). A significant difference in stored carbon related to peat depth was not recognized up to a depth of $2 \mathrm{~m}$ (Fujimoto et al., 1999b). Therefore, assuming that there is a linear relation between peat depth and stored carbon, the belowground carbon of main community types in the coral reef type habitat are estimated to be less than $370 \mathrm{t} \mathrm{C} \mathrm{ha}^{-1}$ for the I and the II communities, between 290 and $860 \mathrm{t} \mathrm{C}$ $\mathrm{ha}^{-1}$ for the III(2)a subunit and between 700 and $1850 \mathrm{t} \mathrm{C} \mathrm{ha}^{-1}$ for the III(2)b subunit. The stored carbon in the estuary type habitat is estimated at about $2200 \mathrm{t} \mathrm{C} \mathrm{ha}^{-1}$. This was found by extrapolating and averaging the data obtained from two boring cores in Fujimoto et al. (1999b), which were $1771 \mathrm{t} \mathrm{C} \mathrm{ha}^{-1}$ (365 cm deep) for a riverward site and $2116 \mathrm{t} \mathrm{C} \mathrm{ha}^{-1}$ (347 cm deep) for a landward site. These calculations assume that the mean depth of the peaty layer is $4 \mathrm{~m}$ and that the lowest layer in these boring cores continues to a depth of $4 \mathrm{~m}$.

\section{Conclusion}

This study clarified the relationship among community type, peat layer thickness, and habitat age of the mangrove forests in Pohnpei Island, Micronesia using the phytosociological and geomorphological data accumulated since 1988. This result enabled us to estimate the belowground carbon storage of the main mangrove community types and to discuss the primary succession and the approximate time required for the mangrove forests on $\mathrm{Pa}$ cific islands in tropics. Analysis of the high-resolution satellite images such as QuickBird will enable us to estimate the spatial distribution of the main mangrove community types and, consequently, to quantify the belowground carbon storage using the results of this study as well as the aboveground.

\section{Acknowledgements}

We are grateful to Mr. Herson Anson, a former Chief of Division of Resource Management, Department of Resource Management \& Development, Pohnpei State Government, the Federated States of Micronesia for his kind support and arrangement for our field research and to all the staff of Forestry, Pohnpei State Government for their cooperation in the field research. We are also grateful to Dr. Katherine C. Ewel, a former Research Ecologist with the Institute of Pacific Islands Forestry, USDA Forest Service for her review of our draft manuscript. This study was financed by Grant-in Aids for Scientific Research of the Japan Society for the Promotion of Science (FY 2002-2005, No. 14255011; FY 2010-2012, No. 22255009 and FY 2013-2014, No. 25282084), the Global Environment Research Fund by Ministry of the Environment, Japan (FY 2003-2007, No. S2-2b(1)) and Nanzan University Pache Research Subsidy I-A-2 (FY 2014).

\section{References}

Ball, M. C. (1988). Ecophysiology of Mangrove. Trees, 2, 129-142. http://dx.doi.org/10.1007/BF00196018

Fujimoto, K., Imaya, A., Tabuchi, R., Kuramoto, S., Utsugi, H., \& Murofushi, T. (1999b). Belowground Carbon Storage of Micronesian Mangrove Forests. Ecological Research, 14, 409-413. http://dx.doi.org/10.1046/j.1440-1703.1999.00313.x

Fujimoto, K., Miyagi, T., \& Kikuchi, T. (1995a). Formative and Maintainable Mechanisms of Mangrove Habitats in Micronesia and the Philippines. In T. Kikuchi (Ed.), Rapid Sea Level Rise and Mangrove Habitat (pp. 9-18). Gifu: Institute for Basin Ecosystem Studies, Gifu University.

Fujimoto, K., Miyagi, T., Kikuchi, T., \& Kawana, T. (1996). Mangrove Habitat Formation and Response to Holocene Sea-Level Changes on Kosrae Island, Micronesia. Mangrove and Salt Marshes, 1, 47-57. http://dx.doi.org/10.1023/A:1025994128221

Fujimoto, K., Miyagi, T., Murofushi, T., Mochida, Y., Umitsu, M., Adachi, H., \& Pramojanee, P. (1999a). Mangrove Habitat Dynamics and Holocene Sea-Level Changes in the Southwestern Coast of Thailand. TROPICS, 8, 239-255. http://dx.doi.org/10.3759/tropics.8.239

Fujimoto, K., Tabuchi, R., Hirata, Y., Ono, K., Taniguchi, S., \& Lihpai, S. (2013). Aboveground Dynamics and Productivity of Major Mangrove Communities on Pohnpei Island, Federated States of Micronesia. Global Environmental Research, 17, 207-214.

Fujimoto, K., Tabuchi, R., Mori, T., \& Murofushi, T. (1995b). Site Environments and Stand Structure of the Mangrove Forests on Pohnpei Island, Micronesia. JARQ, 29, 275-284.

Imanishi, K., \& Kira, T. (1944). Mangrove. In K. Imanishi (Ed.), The Ponape Island: Ecological Study (pp. 62-91). Tokyo: Shokoshoin (Reprinted Edition: Kodansha 1975). 
Kikuchi, T. (Ed.) (1995). Rapid Sea Level Rise and Mangrove Habitat. Gifu: Institute of Basin Ecosystem Studies, Gifu University.

Kikuchi, T., Mochida, Y., Miyagi, T., Fujimoto, K., \& Tsuda, S. (1999). Mangrove Forests Supported by Peaty Habitats on Several Islands in the Western Pacific. TROPICS, 8, 197-205. http://dx.doi.org/10.3759/tropics.8.197

Kitao, M., Utsugi, H., Kuramoto, S., Tabuchi, R., Fujimoto, K., \& Lihpai, S. (2003). Light-Dependent Photosynthetic Characteristics Indicated by Chlorophyll Fluorescence in Five Mangrove Species Native to Pohnpei Island, Micronesia. Physiologia Plantarum, 117, 376-382. http://dx.doi.org/10.1034/j.1399-3054.2003.00042.x

MacLean, C. D., Cole, T. G., Whitesell, C. D., Falanruw, M. V., \& Ambacher, A. H. (1986). Vegetation Survey of Pohnpei, Federated States of Micronesia. Resource Bulletin PSW-18, Berkeley, CA: Pacific Southwest Forest and Range Experiment Station, USDA Forest Service.

Miyagi, T., \& Fujimoto, K. (1989). Geomorphological Situation and Stability of Mangrove Habitat at Truk Atoll and Ponape Island in the Federated States of Micronesia. Science Reports of Tohoku University, 7th Series (Geography), 39, 25-52.

Miyagi, T., Kikuchi, T., \& Fujimoto, K. (1995). Late Holocene Sealevel Changes and the Mangrove Peat Accumulation/ Habitat Dynamics in the Western Pacific Area. In T. Kikuchi (Ed.), Rapid Sea Level Rise and Mangrove Habitat (pp. 19-26). Gifu: Institute for Basin Ecosystem Studies, Gifu University.

Mochida, Y., Kikuchi, T., Fujimoto, K., Hirata, Y., \& Tabuchi, R. (2006). A Phytosociological Study of the Mangrove Forests on Pohnpei Island, Micronesia. In R. Tabuchi (Ed.), Evaluation of the Carbon Fixation and Organic Matter Decomposition Functions in Natural Mangrove Forests (pp. 4-10). Final Report of Study Supported by Grant-In Aid for Scientific Research (A)(2), Japan Society for the Promotion of Science, Tsukuba: Forestry and Forest Products Research Institute.

Omoto, K. (1997). Radiocarbon Dating Reports of Nihon University, No. 5. Proceedings of the Institute of Natural Sciences, Nihon University, 33, 1-41.

Petteys, E. Q. P., Peter, S., Rugg, R., \& Cole, T. G. (1986). Timber Volumes in the Mangrove Forests of Pohnpei, Federated States of Micronesia. Resource Bulletin PSW-19, Berkeley, CA: Pacific Southwest Forest and Range Experiment Station, USDA Forest Service.

Tabuchi, R. (Ed.) (2006). Evaluation of the Carbon Fixation and Organic Matter Decomposition Functions in Natural Mangrove Forests. Final Report of Study Supported by Grant-In Aid for Scientific Research (A)(2), Japan Society for the Promotion of Science, Tsukuba: Forestry and Forest Products Research Institute.

Thom, B. G. (1967). Mangrove Ecology and Deltaic Geomorphology: Tabasco, Mexico. Journal of Ecology, 55, 301-343. http://dx.doi.org/10.2307/2257879

Yamanaka, M., \& Kikuchi, T. (1995). Pollen Analytical Studies of the Holocene Deposits from Kosrae and Pohnpei Islands, Micronesia. In T. Kikuchi (Ed.), Rapid Sea Level Rise and Mangrove Habitat (pp. 45-47). Gifu: Institute for Basin Ecosystem Studies, Gifu University. 
Scientific Research Publishing (SCIRP) is one of the largest Open Access journal publishers. It is currently publishing more than 200 open access, online, peer-reviewed journals covering a wide range of academic disciplines. SCIRP serves the worldwide academic communities and contributes to the progress and application of science with its publication.

Other selected journals from SCIRP are listed as below. Submit your manuscript to us via either submit@scirp.org or Online Submission Portal.
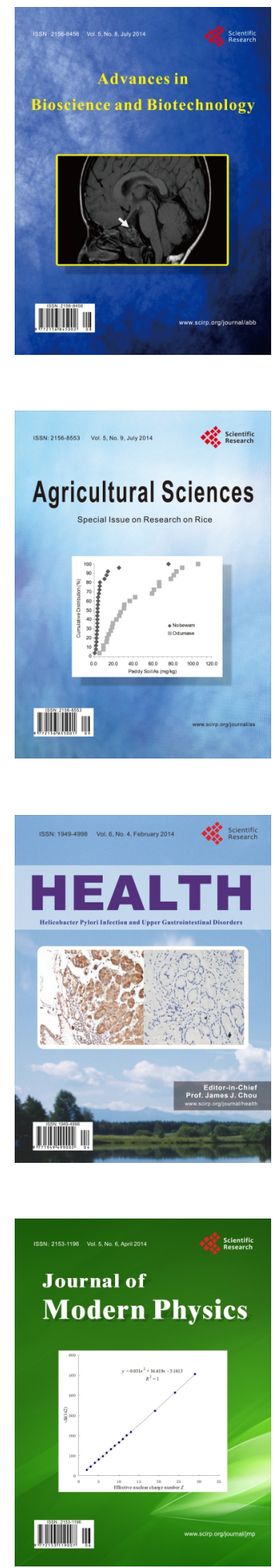
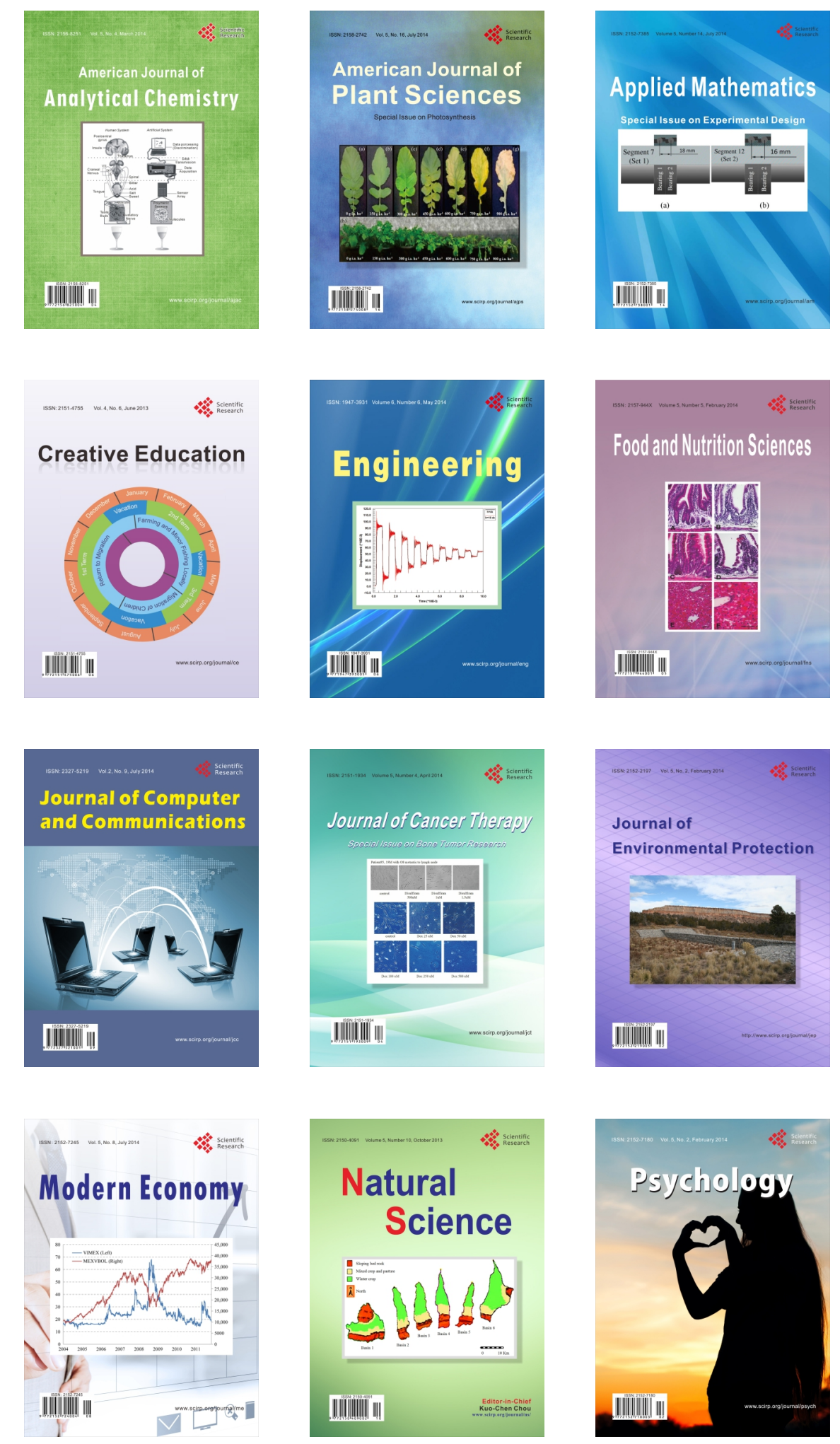